\title{
ANALISIS BAKTERI ENTERO TOKSIGENIC ESCHERICHIA COLI ( ETEC) DENGAN METODE (BGLB) PADA DEPOT AIR MINUM ISI ULANG DI PEMUKIMAN KUMUH.
}

\author{
Rapael Ginting, Ferry Boy Chandra Siahaan \\ Universitas Prima Indonesia \\ Email: rafaelginting@unprimdn.ac.id
}

\begin{abstract}
Based on research conducted at the drinking water depot in Mabar Medan Deli and the Environmental Health Engineering Laboratory of Medan City using the BGLT method with Environmental Sanitation and Personal Hygiene by testing and analyzing the Escherichia Coli bacterial contamination, it can be concluded that the Chi-Square test results are negative analysis effectiveness. in drinking water it is declared not contaminated with ecoli, as well as in gallon washing places, must use soap of the same kind and what is needed around it is kept as clean as possible, if it is dirty it can cause diarrhea. With this environmental sanitation, water quality can be maintained properly and does not affect DAMIU. Environmental cleanliness must also be improved, the location of the business should be specifically for drinking water production, not mixed with other businesses because this can cause pollution to DAMIU's business so that it does not cause diarrhea for anyone who needs drinking water. whereas if the results of the AMIU quality inspection $>0$ in $100 \mathrm{ml}$ sample (positive) in drinking water, then the calculation results will be obtained with a p-value $(0.001<0.005)$ then $\mathrm{Ha}$ is accepted and Ho is rejected so that the BGLB method is effective against the examination of Escherichia Coli bacteria contamination on refill drinks where the water quality is good and clean in the depot. Stated contaminated with ecoli. This study is an observational study with a cross-sectional approach. The sample used 15 samples, the technique used is purposive sampling
\end{abstract}

Keywords : Efektifitas BGLB, Entero toksigenic Escherichia coli

\section{PENDAHULUAN}

Istilah jenis air sangat banyak di indonesia salah satu contohnya Depot Air Minum Isi Ulang adalah badan usaha yang mengelola air minum untuk keperluan masyarakat dalam bentuk curah dan tidak dikemas dari segi harga lebih murah dari pada air minum dalam kemasan yang sejenisnya, Masyarakat lebih memilih air minum bentuk curah dan tidak kemas karena harga sangat terjangkau, murah dan praktis dan dapat di jangkau oleh masyarakat indonesia, itulah salah satu yang menjadi alasan mengapa air minum 
isi ulang sangat di minati selain dari segi kualitasnya yang sudah di akui oleh Peraturan Menteri kesehatan Kesehatan No. 492 Tahun 2010 (Fathoni Afif dkk, 2015)

Berdasarkan hasil penelitian Rahayu, dkk (2013), statistic dari hasil uji coba nilai dari suatu $p$ value $<0,005$ hal ini membuktikan bahwa adanya hubungan antara kualitas

mikrobiologi air baku, proses filtrasi , dan proses densinfeksi yang signifikan. Hal tersebut dapat di pengaruhi karena masih banyaknya depot air minum isi ulang di pada daerah tersebut yang kurang memperhatikan sanitasi lingkungan pada depot tersebut seperti lantai pada depot air yang licin dan tidak kedap air, saluran pembuangan air limbah yang terbuka dan alirannya tidak lancar, serta masih banyaknya depot air.

Pada Penelitian sebelumnya Fathoni Afif (2015) menyebutkan $55,6 \%$ sampel yang tidak memenuhi persyaratan oleh peraturan menteri kesehatan No.492 Tahun 2010, dari sampel 55,6 tersebut terdapat tiga yang mangandung bakteri Escheric hia Coli, dimana dua sampel tersebut adanya bakteri Coliform. Ini akan menunjukkan kualitas suatu produk air minum isi ulang yang di hasilkan.Mengapa demikian karena bakteri tersebut ada pada lingkungan secara alami pada fases manusia dan binatang. Escherichia coli adalah salah satu bakteri yang bisa menyebabkan atau menimbulkan biasanya dapat menyebar melalui fecal oral seperti makanan dan minuman bisa juga melalui kontak atau berhubungan langsung dengan tinja penderita, jika bakteri Escherichia coli ada pada air $100 \mathrm{ml}$ maka air minum tersebut terdapat 500 bakteri, ini akan menyebabkan penyakit yang sering disebut Gastroenteritis atau dengan istilah lain diare (putri, 2013). R yang mematikan desinfektan yaitu sinar ultra violet. Banyak sekali metode yang dibuatkan oleh masyarakat untuk menurukan bakteri Escherichia coli mulai dari ozonisasi dan pencucian tabung juga belum efektif dikarenakan dari hasil pengamatan yang dilakukan adalah sanitasi lingkungan yang kurang memenuhi standart baku mutu permenkes, seperti lokasi depot yang kotor dan sebagian besar depot tidak menyalakan mesin desinfektan (Sinar Ultraviolet), kurang nya kesadaran mengenai higiene dari operator depot air. Oleh karena itu Metode Media Brillian Green Lactose Broth ini merupakan salah satu metode yang yang dianggap efektif untuk mengidentifikasi Keberadaan Bakteri Esherichia Coli dalam Tabung Air Minum. Sekitar Pemukiman kumuh di kota medan banyak yang membuka usaha depot Air minum tanpa melakukan desinfektan tabung dan hanya menggunakan teknik pencuci antabung biasa dan sederhana. Dengan dilakukannya pemeriksaan dengan dengan menggunakan metode BGLB tersebut maka mampu mengurangi tingkat kecemasan pada 
masyrakat terhadap bagimana men gkonsumsi Air Minum isi ulang dan menjadi suatu kesadaran dimana pemilik air minum isi ulang dapat melakukan pemeriksaan air minum dan tabung dengan baik secara bertahap sehingga menghasilkan kualitas yang dapat memberi kepuasana kepada masyarakat.

\section{METODE}

Metode penelitian yang dilakukan pada bakteri air minum isi ulang ini adalah pengumpulan data melalui pendekatan cross sectional, observasi, jurnal. Pada penelitian ini variable yang digunakan adalah variable bebas dan variable terikat dengan waktu yang sama. Jenis

penelitian kuantitatif dengan pende katan quasi eksperimen, sampel 15 sampel, teknik pengambilan mengg unakan purposive sampling dimana depot air minum yang berada di lingkungan kumuh sebanyak 15 orang, cara ukur mll pemeriiksaan sampel air minum dan analisis data univariat dan bivariat

\section{HASIL}

Berdasarkan hasil penelitian yang dilakukan di Depot Air Minum isi Ulang di Sepanjang Kelurahan Mabar Medan Deli Tahun 2020 diperoleh hasil dapat di lihat pada tabel 1 sebagai berikut:

Tabel 1. Hasil pengujian bakteri Entero toksigenic Escherichia coli (ETEC)dengan Metode BGLB Pada Depot Air Minum Isi Ulang Di Kelurahan Mabar Kecamatan Medan Deli Tahun 2020

\begin{tabular}{|c|c|c|c|c|c|c|c|c|}
\hline & \multirow[t]{3}{*}{ M etode BGLB } & \multicolumn{4}{|c|}{ Kontaminasi Ecoli } & \multirow{2}{*}{\multicolumn{2}{|c|}{ Jumlah }} & \multirow[t]{3}{*}{ NilaiP } \\
\hline & & \multicolumn{2}{|c|}{ Ada } & \multicolumn{2}{|c|}{ Tidak Ada } & & & \\
\hline & & $\mathrm{n}$ & $\%$ & $\mathrm{n}$ & $\%$ & $\mathrm{~N}$ & $\%$ & \\
\hline 1 & MemenuhiSyarat & 0 & 0,0 & 3 & 100,0 & 3 & 100,0 & \\
\hline 2 & TidakMemenuhiS yarat & 11 & 91,7 & 1 & 8,3 & 12 & 100,0 & 0,001 \\
\hline & Total & 11 & 73,3 & 4 & 26,7 & 15 & 100,0 & \\
\hline
\end{tabular}

Berdasarkan hasil uji Chi Square efektifitas analisis BGLB terhadap kontaminasi bakteri Escherichia Coli, maka diperoleh hasil perhitungan $(0,001<0,005)$ sebagai nilai $\mathrm{p}$ atau value, maka $\mathrm{Ha}$ diterima dan Ho ditolak sehingga metode BGLB efektif terhadap pemeriksaan kontaminasi bakteri
Escherichia Coli pada depot air minum isi ulang.

Penelitian ini sejalan dengan yang dilakukan Rahayu, dkk (2013), dimana dengan hasil uji statistic didapatkan nilai $\mathrm{p}$ value $<0,005$ hal ini menunjukkan adanya hubungan yng signifikan antara kualitas mikrobiologi air 
baku,proses filtrasi,dan proses densinfeksi. Hal tersebut dapat di pengaruhi karena masih banyaknya depot air minum isi ulang di daerah tersebut yang kurang memperhatikan sanitasi lingkungan pada depot tersebut seperti lantai pada depot air yang licin dan tidak kedap air, dan masih banyaknya depot air yang mematikan desinfektan yaitu sinar ultra violet.

Pada penelitian sebelumnya yang dilakukan Putri, (2015) bahwa bakteri Esceheria coli yang di uji pada air minum isi ulang yang di lakukan di masyarakat bahwa sebagian besar tidak menyediakan tempat yang sebaiknya serta kelengkapan fasilitas da sanitasi yang kurang memadai, seperti menyediakan tempat cuci tangan pada pekerja yang ada di depot air minum tersebut.Berdasarkan hasil uji statatistik yang dilakukan bahwa nilai $p$ yang di peroleh $0,002<$ dari 0,005 nilai $p$, sehingga dapat disimpulkan adanya kontaminasi bakteri coliform depot air minum isi ulang tersebut.

Penelitian ini sejalan dengan penelitian yang dilakukan Yunus dkk, (2015) tentang sanitasi pada pengololahan sampah dengan hasil uji nilai $p=0,032$ ini disebut kontaminasi Escherichia Coli, jadi dapat disimpulkan nilai dari OR dengan 8,500 tidak baik 8.500 kali peluang kontaminasi Escherichia Coli.

Menurut asumsi peneliti yang ditemukan selama meneliti bahwa hampir disetiap depot di 15 depot di
Kelurahan Durian memiliki sanitasi yang buruk, dapat dilihat dari tidak ada nya tempat sampah yang tertutup, dan hampir semua depot tidak dilengkapi dengan air mengalir dengan sabun dan juga saluran pembuangan air limbah yang hanya beberapa saja yang memili. mereka membuang air bekas pencuciannya diteras depot dan sebagian juga air bekasnya dialirkan saja di ruangan depot sehingga hampir semua depot lantainya licin meskipun mudah dibersihkan tetapi sebagian pemilik depot tidak memperhatikannya untuk dibersihkan sehingga ruang depot air minum yang hanya sebagian yang tertata rapi serta warna dinding yang hanya sebagian sudah kotor, terkelupas juga ditemukan depot air minum yang dindingnya lembab.

Pengelola DAMIU seharusnya perlu memperhatikan sanitasi lingk ungan termasuk juga tempat seperti galon atau tangki penampungan air tersebut, tutup, dan perlenkapan lainya seperti sabun cuci tangan, serta tempat pencucian galon, harus menggunakan sabun yang sejenisnya dan apa saja yang di perlukan sekitar nya tetap di jaga sebersih mungkin, jika kotor dapat menyebabkan diare. Dengan adanya sanitasi lingkungan tersebut maka kualitas air dapat terjaga dengan baik dan tidak mempengaruhi DAMIU.

Kebersihan lingkungan juga harus lebih ditingkatkan, lokasi usaha sebaiknya khusus untuk produksi air minum jangan dicampur dengan 
usaha lain, karena hal ini dapat menimbulkan pencemaran pada usaha DAMIU.

\section{KESIMPULAN}

Dari hasil penelitian yang dilakukan Pada Depot Di Kelurahan Mabar Medan Deli dan Laboratorium Balai Teknik Kesehatan Lingkungan Kota Medan tentang Metode Sanitasi Lingkungan dan personal $\mathrm{H}$ igiene dengan Kontaminasi bakteri Escherichia Coli maka dapat disimp ulkan hasil uji Chi Square efektifitas analisis dengan metode Brillian Green Lactose Broth terhadap kontaminasi bakteri Escherichia Coli, maka diperoleh hasil perhitungan dengan nilai $p$ value $(0,001<0,005)$ maka $\mathrm{Ha}$ diterima dan Ho ditolak sehingga metode BGLB

efektif terhadap pemeriksaan konta minasi bakteri Escherichia Coli pada depot air minum isi ulang.

\section{DAFTAR PUSTAKA}

Balai Pelatihan Kesehatan. 2013. Pengawasan Dan Pembinaan Depot Air Minum Isi Ulang (DAMIU) Kurikulum Dan Modul Pelatihan.

Elliott, Tom. dkk. 2013. Mikrobiologi Kedokteran \& Infeksi. Jakarta: EGC.

Fathoni Afif, dkk. 2015 Identifikasi Bakteri Escherichiacoli Pada Air Minum Isi Ulang Yang Dipenogoro Depot Air Minum Isi Ulang Di Kecamatan Padang Selatan.

Hastari,R.,2015.Sanitasi.Jakartaped ia.Availableat:http://jakartape dia.bpadjakarta.net/index.php ?title=Sanitasi_Lingkungan\&ol d id $=31074$ [Accessed Oktober 10, 2018].

Husaini, suriadi dan lenie. (2016). Hubungan Hygiene Sanitasi dengan Kualitas Bakteorologis Depot Air Minum (DAM) di Kabupaten Balangan. Jurnal Kesehatan Lingkungan Indonesia 15(I).

Jawetz, M. A. (2015). Mikrobiologi Kedokteran (25 ed.). (G. F. Brooks, K. C. Carroll, J. S. Butel, S. A. Morse, T. A. Mietzner, Penyunt., A. W. Nugroho, D. Ramadhani, $H$. Santasa, N. Yasdelita, \& K. W. Nimala, Penerj.) New York: Mc Graw Hill

Joko, Tri. Unit Air Baku dalam Sistem Penyediaan Air Minum.

- Edisi Pertama - Yogyakarta; Graha IImu. 2010. ISBN : 978979-756-596-1.

Karame, M., Palandenh, H., Sondakh, R. C. (2014). Hubungan Antara Higiene Sanitasi Depot Air Minum Isi Ulang Dengan Kualitas Bakteriologi Pada Air Minum Di Kelurahan Bailang Dan Molas Kota Manado.

Kurniawan, A., Joseph, W., B., S., Bernadus, J. (2014). Higiene Sanitasi Dan Kualitas Bakteriologis Air Minum Pada Depot Air.

Mairizki F. (2017). Analisi Higiene dan Sanitai Depot Air Minum Isi Ulang (DAMIU) di Sekitar 
Universitas Islam Riau. Jurnal Endurance, Vol 2 No. 3.

Mundiatun \& Daryanto. 2015. Pengelolaan Kesehatan Lingkungan. Gava Media. Yogyakarta

Peraturan Presiden Republik Indonesia Nomor 185 Tahun 2014 Tentang Percepatan Penyediaan Air Minum Dan Sanitasi.

Pradana dan Marsono, 2013. Uji Kualitas Air Minum Isi Ulang di Kecamatan Sukodono, Sidoarjo Ditinjau dari Perilaku dan Pemeliharaan Alat. Sukodono.

Prihatini. 2012 Kualitas air isi ulang pada depot air minum di wilayah Kabupaten Bogor [skripsi]. Depok: Universitas Indonesia.
Putri, Analisis Kualitas Bakteriologis Escherechia Coli Depot Air Minum Di Kabupaten Pasuruan, 2013. Diakses tanggal 9 Oktober 2020

Purba H J. 2011. Kebutuhan dan Cara Pemberian Air Irigasi untuk Tanaman Padi Sawah. Sains dan Teknologi 10(3): 145-150

Ronny, Syam, D. . (2015). Studi Kondisi Sanitasi Dengan Kualitas Bakteriologis Depot Air Minum Isi Ulang di Kecamatan Panakkukang Kota Makassar. Higiene, 2(2), 81-90.

Sofiyanto, dkk. 2016. Hubungan Sanitasi Lingkungan, Personal Higiene Dengan Jumlah Bakteri Escherichia Coli Pada Damiu Di Kawasan Universitas Diponeg orotembalang. Jurnal Kesehatan Masyarakat. 